\title{
Pengaruh Kepemimpinan, Budaya Organisasi dan Motivasi Kerja terhadap Kinerja Karyawan PT. Tunas Perkasa Tekindo
}

\author{
${ }^{*}$ Roni Fadli' ${ }^{1}$, Hasanudin ${ }^{2}$ \\ 1,2 Universitas Pamulang, Tangerang Selatan, Banten, Indonesia \\ E-mail: dosen02328@unpam.ac.id
}

\begin{tabular}{l} 
Article Info \\
\hline Article History \\
Received: $2021-07-12$ \\
Revised: $2021-08-15$ \\
Published: 2021-09-08 \\
\\
Keywords: \\
Leadership; \\
Organizational Culture; \\
Work Motivation; \\
Employee Performance.
\end{tabular}

Artikel Info

Sejarah Artikel

Diterima: 2021-07-12

Direvisi: 2021-08-15

Dipublikasi: 2021-09-08

Kata kunci:

Kepemimpinan;

Budaya Organisasi;

Motivasi Kerja;

Kinerja Karyawan.

\begin{abstract}
This research is an associative research, where the aim is to find out or find the relationship between the independent variable and the dependent variable. The population in this study amounted to 100 respondents PT. Tunas Perkasa Tekindo. The sampling technique in this study is a saturated sample, where all members of the population are used as samples. Thus the sample in this study the sample used was 100 respondents. This study aims to determine the effect of the results of this study showing that there is a partial influence between leadership on positive performance of $t$ count 15.723 at a significance level of 0.000 . There is a partial influence between organizational culture on positive performance of t count 10.148 at a significance level of 0.000 . And the partial effect of work motivation on employee performance is positive for $t$ count 13,174 with a significance level of 0.000 . Meanwhile, there is a simultaneous relationship between leadership, organizational culture and work motivation on positive employee performance of $f$ count 87.670 with a significance level of 0.000 .
\end{abstract}

\section{PENDAHULUAN}

Perubahan lingkungan bisnis yang begitu cepat dan bersifat dinamis mengharuskan organisasi-organisasi yang ada dalam suatu sektor jasa untuk senantiasa berusaha meningkatkan kinerjanya, sehingga dalam kondisi ini akan membutuhkan sumber daya manusia (human resources) yang berkualitas serta dapat menjalankan organisasi. Sumber daya manusia (human resources) yang berkualitas merupakan aset bagi organisasi karena perannya sebagai pelaksana kebijakan dan yang dapat menjalankan kegiatan operasional organisasi tersebut, untuk itu dalam mencapai tujuan organisasi dibutuhkan peran sumber daya manusia (human resources) yang memadai dalam mendorong kinerja dan sehingga dapat berkompetisi dengan organisasi lainnya. Hal ini didukung oleh Greer dalam Nazarrudin Malik (2010:153) bahwa manajemen sumber daya manusia merupakan kunci untuk mencapai keunggulan kompetitif.

Menurut Suntoro (1999:12) Kinerja adalah hasil kerja yang dicapai oleh seseorang atau kelompok orang dalam suatu organisasi sesuai dengan wewenang dan tanggung jawab masingmasing dalam rangka mencapai tujuan organisasi yang bersangkutan secara legal, tidak melanggar hukum dan sesuai dengan moral dan etika. Kinerja merupakan hasil yang dicapai dari perilaku anggota organisasi yang mencerminkan adanya suatu keberhasilan dalam melaksanakan 
tugasnya. Kinerja itu sendiri akan dipengaruhi oleh faktor internal dan eksternal. Untuk sisi internal menyangkut dalam diri pribadi karyawan tersebut, komitmennya dalam organisasi dan keyakinan akan kemampuannya untuk melakukan suatu pekerjaan tertentu dengan mencapai keberhasilan yang oleh Bandura dan Syahirudin (2012:1) itu disebut kinerja. Sedangkan dari sisi eksternal dipengaruhi oleh kepemimpinan yang diciptakan oleh lingkungan tempat mereka berkerja. Dari uraian tersebut dapat disimpulkan bahwa kinerja organisasi adalah fungsi hasil-hasil pekerjaan yang ada dalam perusahaan yang dipengaruhi faktor intern dan ekstern organisasi dalam mencapai tujuan yang ditetapkan selama periode waktu tertentu.

Berdasarkan wawancara dengan Manajer HRD PT. Tunas Perkasa Tekindo beliau menuturkan mengingat banyaknya pembelian besi dan baja dari tahun ke tahun terus meningkat. Hal ini berdampak pada semakin banyaknya permasalahan pendistribusian penjualan besi dan baja. Maka perlu ditangani secara serius dan professional. Sehingga Pimpinan merasa kinerja para karyawannya yang ada pada saat ini dirasa belum optimal dan terus ditingkatkan serta dikembangkan, seperti diciptakannya budaya organisasi yang kondusif, mendorong lahirnya komitmen para karyawannya dan meningkatkan kinerja karyawannya yang lebih baik, agar dalam menangani berbagai macam permasalahan pelanggan dapat terselesaikan dengan cepat.

Selain pembahasan teoritis diatas, penelitian ini juga didukung oleh hasil empiris oleh Syahiruddin (2012) terhadap beberapa subjek penelitian beberapa perusahaan, hasil yang didapat menunjukkan bahwa budaya organisasi dan motivasi yang baik akan dapat memberikan rasa betah bagi karyawan, selain itu hasil penelitiannya juga menjelaskan karyawan dengan kinerja yang tinggi dan tingkat disiplin yang baik akan menghasilkan kinerja yang lebih baik. Kinerja seseorang dapat diprediksi berdasarkan seberapa besar orang tersebut memiliki kinerja yang baik dan keseriusan dalam bekerja didukung dengan gaya kepemimpinan yang menyenangkan, maka akan melahirkan kinerja yang baik. Selain itu seseorang yang memiliki kinerja yang baik dan menjaga kinerja yang baik pada prakteknya dapat mengimplementasikan sesuatu dengan baik maka kinerjanya dalam melaksanakan suatu pekerjaan juga akan lebih baik. Sedangkan kepemimpinan menjadi stimulus pendukung terciptanya seorang karyawan memiliki kinerja yang baik dan menjaga keseriusan dalam bekerja.

Berdasarkan penjelasan diatas, salah satu organisasi yang ingin meningkatkan kinerja para karyawannya adalah PT. Tunas Perkasa Tekindo yang beralamat Jalan Radio Dalam Raya No.48, Kebayoran Baru, Kota Jakarta Selatan, tidak terlepas dari penjelasan PT. Tunas Perkasa Tekindo juga memberikan perhatian khususnya pada kinerja para karyawannya. Sebagaimana yang didukung oleh peraturan perundangundangan ketenagakerjaan, Meski sudah diterapkan kepemimpinan yang mengarah pada lingkungan yang kondusif, mendorong lahirnya kinerja para para karyawannya dengan pemberian insentif serta penerapan aturan kinerja. Akan tetapi seiring semakin banyaknya pelanggan, PT. Tunas Perkasa Tekindo merasa ketiga aspek diatas terkait kinerja belum optimal. Artinya diperlukan budaya organisasi dan motivasi yang lebih baik lagi, sehingga mendapatkan kinerja yang lebih baik lagi.

\section{Tinjauan Pustaka}

1. Kepemimpinan

Secara teoritis telah banyak studi tentang kepemimpinan dan memberi batasan yang relatif beragam tentang definisi kepemimpinan, seperti Veithzal dan Deddy (2003:2) "kepemimpinan secara luas meliputi proses memengaruhi dalam menentukan tujuan organisasi, memotivasi perilaku pengikut untuk mencapai tujuan". Memengaruhi untuk memperbaiki kelompok dan budayanya, Menurut Stephen P. Robbins (2006:432) "bahwa kepemimpinan sebagai kemampuan untuk mempengaruhi kelompok menuju pencapaian sasaran". Sumber dari pengaruh ini dapat bersifat formal, seperti yang di sajikan oleh kepemilikan peringkat manajerial dalam organisasi. Karena posisi manajemen muncul bersama sejujmlah tingkat wewenang yang di rancang secara formal, seseorang dapat menjalankan peran kepemimpinan semata-mata karena kedudukannya dalam organisasi.

2. Budaya Organisasi

Menurut Susanto (1997:3) budaya organisasi adalah nilai-nilai yang menjadi pedoman sumber daya manusia untuk menghadapi permasalahan eksternal dan usaha penyesuaian integrasi ke dalam permasalahan, sehingga masing-masing anggota organisasi harus memahami nilai- 
nilai yang ada dan bagaimana mereka harus bertindak atau berperilaku, Pendapat Chatab (2007:10) mengenai budaya organisasi yaitu merupakan keyakinan, tata nilai dan persepsi umumyang dianut secara luas dalam mmembentuk dan memberi arti kepada perilaku karyawan sehingga menjadi kebiasaan yang relatif sulit diubah. Sedangkan menurut Robbins (2001) dalam Chatab (2007:10) menyebutkan budaya organisasi merupakan suatu sistem dari makna atau arti besama yang dianut oleh para anggotanya yang membedakan organisasi dari organisasi lainnya,

Menurut Chatab (2007:10) mengenai budaya organisasi yaitu merupakan keyakinan, tata nilai dan persepsi umum yang dianut secara luas dalam mmembentuk dan memberi arti kepada perilaku karyawan sehingga menjadi kebiasaan yang relatif sulit diubah.Sedangkan menurut Robbins (2001) dalam Chatab (2007:10) menyebutkan budaya organisasi merupakan suatu sistem dari makna atau arti besama yang dianut oleh para anggotanya yang membedakan organisasi dari organisasi lainnya.

\section{Motivasi Kerja}

Menurut Vroom dalam Ngalim Purwanto (2006: 72), motivasi mengacu kepada suatu proses mempengaruhi pilihan-pilihan individu terhadap bermacam-macam bentuk kegiatan yang dikehendaki. Kemudian John P. Campbell, dkk mengemukakan bahwa motivasi mencakup di dalamnya arah atau tujuan tingkah laku, kekuatan respons, dan kegigihan tingkah laku. Di samping itu, istilah tersebut mencakup sejumlah konsep dorongan (drive), kebutuhan (need), rangsangan (incentive), ganjaran (reward), penguatan (reinforcement), ketetapan tujuan (goal setting), harapan (expectancy), dan sebagainya.

4. Kinerja

Menurut Hani Handoko (2002) mengistilahkan Kinerja (performance) dengan prestasi kerja yaitu "proses melalui mana organisasi mengevaluasi atau menilai prestasi kerja pegawai". Kinerja pegawai (prestasi kerja) adalah hasil kerja secara kualitas dan kuantitas yang dicapai oleh seorang pegawai dalam melaksanakan tugasnya sesuai dengan tanggung jawab yang diberikan kepadanya. Mangkunegara (2005:9)

\section{METODE PENELITIAN}

Jenis penelitian yang dipakai adalah asosiatif, dimana tujuannya adalah untuk mengetahui atau mencari keterhubungan antara variabel independen terhadap variabel dependennya. Dalam menganalisis data digunakan uji validitas, uji reliabilitas, analisis regresi linier sederhana, analisis koefisien korelasi, analisis koefisien determinasi dan pengujian hipotesis, Populasi dalam penelitian ini berjumlah 100 responden PT. Tunas Perkasa Tekindo. Teknik pengambilan sampling dalam penelitian ini adalah sampel jenuh, dimana semua anggota populasi dijadikan sebagai sampel. Dengan demikian sampel dalam penelitian ini sampel yang digunakan berjumlah 100 responden,

\section{HASIL DAN PEMBAHASAN}

\section{A. Hasil Penelitian}

1. Analisis Deskriptif

Melihat dengan Pengujian multikolinieritas bertujuan untuk mengetahui ada tidaknya hubungan yang sempurna atau sangat tinggi antara variabel-variabel independen dalam model regresi. Konsekuensi dari adanya hubungan (korelasi) yang sempurna atau sangat tinggi antara variabel-variabel independen adalah koefisien regresi dan simpangan baku (standard deviation) variabel independen menjadi sensitif terhadap perubahan data serta tidak memungkinkan untuk mengisolir pengaruh individual variabel independen terhadap variabel dependen, Ghozali (2005), Dalam uji Multikolinieritas dapat dilakukan dengan 2 (dua) cara pengujian, yakni:

a) Melihat Nilai Tolerance

1) Jika nilai Tolerance > dari 0,10, maka artinya tidak terjadi multikolinieritas terhadap data yang diuji.

2) Jika nilai Tolerance < dari 0,10 , maka artinya terjadi multikolinieritas terhadap data yang diuji.

\section{b) Melihat Nilai Variance Inflation Factor (VIF)}

a) Jika nilai VIF < dari 10,00 maka artinya tidak terjadi multikolinieritas terhadap data yang diuji.

b) Jika nilai VIF > dari 10,00 maka artinya terjadi multikolinieritas terhadap data yang diuji. 


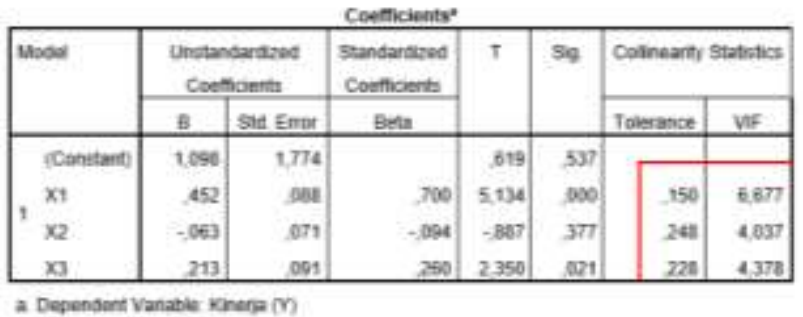

Berdasarkan hasil tabel diatas diketahui bahwa, nilai tolerance variabel Kepemimpinan (X1) sebesar 0,150, Budaya Organisasi (X2) sebesar 0,248, dan Motivasi Kerja (X3) sebesar 0,228 lebih besar dari batas toleransi 0,10 , maka dapat disimpulkan tidak terjadi multikolinieritas (X1, X2, X3 > 0,1). Sedangkan nilai VIF variabel Kepemimpinan (X1) sebesar 6,677, Budaya Organisasi (X2) sebesar 4,037, dan Motivasi Kerja (X3) sebesar 4,378 lebih kecil dari batasan VIF 10,00. Sehingga dapat disimpulkan bahwa tidak terjadi multikolinearitas (X1, X2, X3 < 10,00).

\section{Analisis Verifikatif}

Pada analisis ini dimaksudkan untuk mengetahui pengaruh variabel independen terhadap variabel dependen. Adapun hasil pengujian sebagai berikut:

a) Analisis Regresi Linier Sederhana

Uji regresi ini dimaksudkan untuk mengetahui perubahan variabel dependen jika variable independen mengalami perubahan. Adapun hasil pengujiannya sebagai berikut:

Uji Regresi Sedehana Kepemimpinan terhadap Kinerja Karyawan (Y)

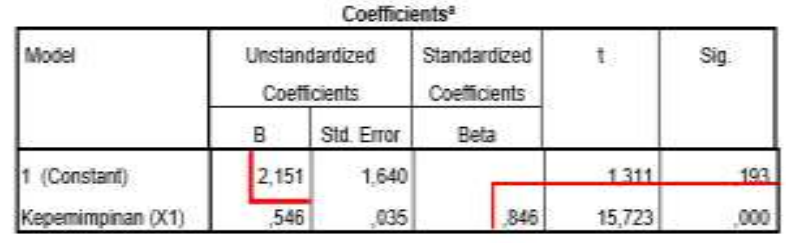

a. Dependent Variable: Kinerja (Y)

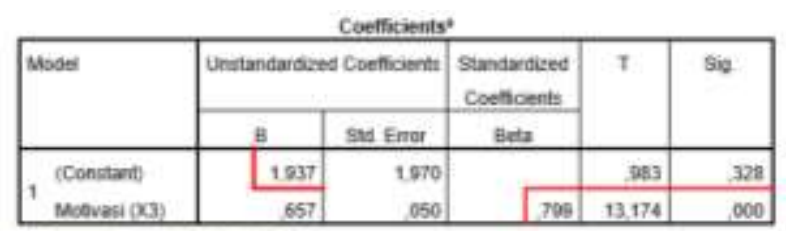

n. Depencent Vaciatie Kaneja in

Dari tabel diatas didapat nilai $t_{\text {hitung }} 15,723$ untuk Kepemimpinan (X1) dan nilai $t_{\text {tabel }}$ adalah 1,660 (df= n-k, 100-2=98), apabila nilai $t_{\text {hitung }}>t_{\text {tabel}}$, maka dapat disimpulkan bahwa terdapat pengaruh yang positif secara parsial, sebaliknya apabila nilai $t_{\text {hitung }}<t_{\text {tabel, }}$ maka dapat disimpulkan bahwa tidak terdapat pengaruh yang positif. Dari hasil tabel Coefficients diatas dapat disimpulkan bahwa nilai thitung Kepemimpinan (X1) 15,723> $t_{\text {tabel }} 1,660$, maka dapat disimpulkan terdapat pengaruh yang positif antara variabel Kepemimpinan (X1) secara parsial (sendiri-sendiri) terhadap variabel Kinerja Karyawan (Y).

Uji Regresi Sedehana Budaya Organisasi (X2) terhadap Kinerja Karyawan (Y)

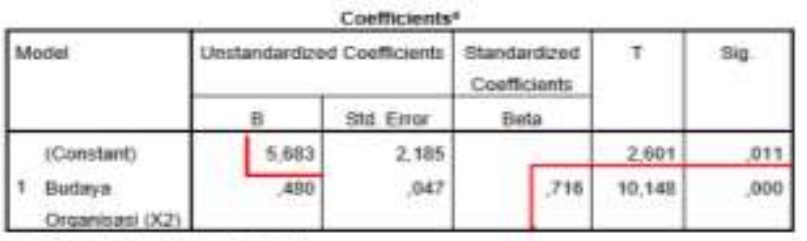

a. Depenoent Variabe Kinege (r)

Dari tabel diatas didapat nilai $t_{\text {hitung }} 10,148$ untuk Pelatihan (X2) dan nilai $t_{\text {tabel }}$ adalah $1,660(\mathrm{df}=\mathrm{n}-\mathrm{k}, 100-2=98)$. Apabila nilai $t_{\text {hitung }}>t_{\text {tabel, }}$ maka dapat disimpulkan bahwa terdapat pengaruh yang positif secara parsial, sebaliknya apabila nilai $t_{\text {hitung }}<t_{\text {tabel, }}$ maka dapat disimpulkan bahwa tidak terdapat pengaruh yang positif. Dari hasil tabel Coefficients diatas dapat disimpulkan bahwa nilai thitung Budaya Organisasi (X2) 10,148 > t tabel 1,660, maka dapat disimpulkan terdapat pengaruh yang positif antara variabel Budaya Organisasi (X2) secara parsial (sendiri-sendiri) terhadap variabel Kinerja Karyawan (Y).

Uji Regresi Sedehana Motivasi Kerja (X3) terhadap Kinerja Karyawan ( $Y$ )

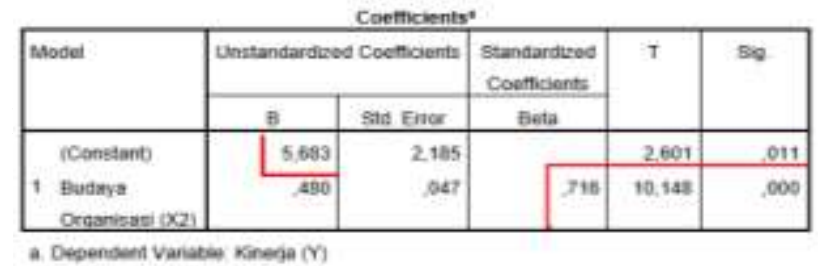

Motivasi Kerja (X3) dan nilai $t_{\text {tabel }}$ adalah 1,660 (df= n-k, 100-2= 98), apabila nilai $t_{\text {hitung }}>t_{\text {tabel, }}$ maka dapat disimpulkan bahwa terdapat pengaruh yang positif secara parsial, sebaliknya apabila nilai $t_{\text {hitung }}<t_{\text {tabel, }}$ maka dapat disimpulkan bahwa tidak terdapat pengaruh yang positif. Dari hasil tabel Coefficients diatas dapat disimpulkan terdapat pengaruh yang positif antara variabel terdapat pengaruh 
yang positif antara variabel Motivasi Kerja (X3) secara parsial (sendiri-sendiri) terhadap variabel Kinerja Karyawan (Y).

Uji F digunakan untuk mengetahui pengaruh variabel bebas secara bersamasama (simultan) terhadap variabel terikat. Dalam uji $F$ dapat dilihat pada tabel ANOVA pada kolom $F$ untuk melihat pengaruh positif dan kolom significance untuk melihat signifikansi, Berikut akan peneliti sajikan hasil uji $\mathrm{F}$ antara variabel independen Kepemimpinan (X1), Budaya Organisasi (X2) dan Motivasi Kerja (X3) terhadap variabel dependen Kinerja Karyawan (Y) dengan bantuan program SPSS versi 21.0:

\begin{tabular}{|c|c|c|c|c|c|c|}
\hline \multicolumn{2}{|c|}{ Moder } & $\begin{array}{l}\text { Sum of } \\
\text { Sganates }\end{array}$ & of & Mean square & F & sig \\
\hline \multirow{3}{*}{1} & Regression & 2615.845 & J & e719ab & 67, 070 &, $000^{\circ}$ \\
\hline & Resioua & 954,785 & 16 & 9.946 & & \\
\hline & Total & 3570,640 & $\infty$ & & & \\
\hline
\end{tabular}

Dari tabel diatas didapat nilai $\mathrm{F}_{\text {hitung }} 87,670$ untuk variabel Kepemimpinan (X1), Budaya Organisasi (X2) dan Motivasi Kerja (X3) dan nilai $f_{\text {tabel }}$ adalah 2,70 (df1=k-1,3$1=2$, df $2=n-k, 100-2=98$ ). Apabila nilai $f_{\text {hitung }}$ $>\mathrm{f}_{\text {tabel, }}$ maka dapat disimpulkan bahwa terdapat pengaruh yang positif secara simultan, sebaliknya apabila nilai $\mathrm{f}_{\text {hitung }}<$ $\mathrm{f}_{\text {tabel, }}$ maka dapat disimpulkan bahwa tidak terdapat pengaruh yang positif secara simultan, dari hasil tabel ANOVA diatas dapat disimpulkan bahwa nilai $f_{\text {hitung }}$ sebesar 87,670 > $\mathrm{ft}_{\text {tabel }}$ 2,70, maka dapat disimpulkan terdapat pengaruh yang positif antara variabel Kepemimpinan (X1), Budaya Organisasi (X2) dan Motivasi Kerja (X3) secara simultan (bersama-sama) terhadap variabel Kinerja Karyawan (Y).

Dalam Uji Signifikansi apabila nilai Sig. < dari Signifikansi $\alpha=0,05$, maka dapat disimpulkan bahwa terdapat pengaruh yang Signifikan antara Kepemimpinan (X1), Budaya Organisasi (X2) dan Motivasi Kerja (X3) secara simultan terhadap Kinerja Karyawan (Y), begitu pula sebaliknya apabila nilai Sig $>$ dari Sig $\alpha=$ 0,05 dapat disimpulkan tidak terdapat pengaruh yang signifikan antara Kepemimpinan (X1), Budaya Organisasi (X2) dan Motivasi Kerja (X3) secara simultan terhadap Kinerja Karyawan (Y).
Dari tabel diatas dapat disimpulkan nilai Sig. Kepemimpinan (X1), Budaya Organisasi (X2) dan Kompensasi (X3) sebesar $0,000<0,05$, maka kesimpulannya terdapat pengaruh yang signifikan antara Gaya Kepemimpinan (X1), Pelatihan (X2) dan Motivasi Kerja (X3) secara simultan terhadap Kinerja Karyawan (Y).

Dengan demikian dapat dikatakan bahwa Hipotesis pada penelitian ini setelah di uji secara simultan terhadap semua variabel independen; $\mathrm{X}_{1}, \mathrm{X}_{2}$ dan $\mathrm{X}_{3}$ terhadap variabel dependen (Y), maka hasilnya Hipotesis diterima (Ha. Positif).

\section{B. Pembahasan}

Berdasarkan dari hasil pengolahan data statistik yang sudah diteliti, maka dapat diungkapkan pembahasan penelitian antara pengaruh Kepemimpinan, Budaya Organisasi, dan Motivasi Kerja terhadap Kinerja Karyawan PT. Tunas Perkasa Tekindo baik secara parsial dan simultan, adalah sebagai berikut:

1. Pengaruh Kepemimpinan (X1) secara parsial terhadap Kinerja Karyawan (Y)

Persepsi Kepemimpinan pimpinan dari persepsi responden yang diperoleh melalui angket, menunjukan bahwa Kepemimpinan pimpinan pada katagori baik. Dari rumusan masalah yang telah diungkapkan pada Bab sebelumnya, bahwa dari hasil uji hipotesis dengan melakukan uji t (uji regresi linier sederhana), ditemukan bahwa terdapat pengaruh yang positif dan signifikan secara parsial antara Kepemimpinan (X1) terhadap Kinerja Karyawan (Y) pada PT. Tunas Perkasa Tekindo. Hal ini dibuktikan dengan hasil uji t dengan menggunakan bantuan program SPSS versi 21.0, dimana $t_{\text {hitung }}$ sebesar 15,723 lebih besar dari $t_{\text {tabel }}$ $1,660(15,723>1,660)$ dengan tingkat probabilitas ( $\alpha$ sig) sebesar 0,000 lebih kecil dari $\alpha=0,05(0,000<0,05)$, sehingga untuk hipotesis pertama diterima (H1 diterima).

2. Pengaruh Budaya Organisasi (X2) secara parsial terhadap Kinerja Karyawan (Y)

Dari hasil olah data statistik atas jawaban responden, ditemukan bahwa persepsi variabel Budaya Organisasi (X2) pada PT. Tunas Perkasa Tekindo pada katagori baik. Hipotesis kedua yang diajukan oleh penulis bahwa terdapat 
pengaruh yang positif dan signifikan secara parsial antara Budaya Organisasi (X2) terhadap Kinerja Karyawan (Y) diterima dengan hasil sebagai berikut, dimana $t_{\text {hitung }}$ sebesar 10,148 lebih besar dari tabel 1,660 $(10,148>1,660)$ dengan tingkat probabilitas ( $\alpha$ sig) sebesar 0,000 lebih kecil dari $\alpha=0,05(0,000<0,05)$, sehingga untuk hipotesis kedua diterima (H2 diterima).

3. Pengaruh Motivasi Kerja (X3) secara parsial terhadap Kinerja Karyawan (Y)

Dari hasil olah data statistik atas jawaban responden, ditemukan bahwa persepsi variabel Motivasi Kerja (X3) pada PT. Tunas Perkasa Tekindo pada katagori baik. Hipotesis ketiga yang diajukan oleh penulis bahwa terdapat pengaruh yang positif dan signifikan secara parsial antara Motivasi Kerja (X3) terhadap Kinerja Karyawan (Y) diterima dengan hasil sebagai berikut, dimana $t_{\text {hitung }}$ sebesar 13,174 lebih besar dari $t_{\text {tabel }} 1,660(13,174$ $>1,660)$ dengan tingkat probabilitas $(\alpha$ sig) sebesar 0,000 lebih kecil dari $\alpha=0,05$ $(0,000<0,05)$, sehingga untuk hipotesis ketiga diterima (H3 diterima).

4. Pengaruh Kepemimpinan (X1), Budaya Organisasi (X2) dan Motivasi Kerja (X3) secara simultan terhadap variabel dependen Kinerja Karyawan (Y)

Berdasarkan hasil olah data statistik diatas dengan menggunakan program SPSS versi 21.0, akan menjelaskan pengaruh Kepemimpinan (X1), Budaya Organisasi (X2) dan Motivasi Kerja (X3) secara simultan terhadap Kinerja Karyawan (Y). Dari tabel diatas Nilai $\mathrm{F}_{\text {hitung }}$ dalam tabel ANOVA sebesar 87,670 sedangkan $F_{\text {tabel }}$ sebesar 2,70, maka data tersebut dapat dikatakan terjadi pengaruh simultan yaitu $\mathrm{F}_{\text {hitung }}$ lebih besar dari $\mathrm{F}_{\text {tabel }}(87,670>2,70)$ sehingga berpengaruh positif. Apabila dihitung dari nilai signifikasi menghasilkan nilai sig. $0,000<\alpha=0,05$, maka hasil yang di dapat berpengaruh secara signifikan, sehingga untuk hipotesis keempat diterima (H4 diterima).

\section{SIMPULAN DAN SARAN}

\section{A. SIMPULAN}

Berdasarkan hasil penelitian dan pembahasan, maka dapat ditarik kesimpulan diantaranya:
1) Terdapat pengaruh positif dan signifikan Kepemimpinan $\left(\mathrm{X}_{1}\right)$ terhadap Kinerja Karaywan (Y). Hal ini ditunjukan oleh model regresi $\mathrm{y}=2,151+0,846 \mathrm{X}_{1}$ dan nilai $\mathrm{t}_{\text {hitung }}>$ $t_{\text {tabel }}(15,723>1,660)$, dengan nilai signifikansi sebesar $0,00<\alpha=0,05$, maka Hipotesis $\left(\mathbf{H}_{\mathbf{a}}\right.$ diterima). Nilai Koefisien Determinasi $R$ Square $\left(\mathrm{R}^{2}\right)$ sebesar 0,716, maka dapat disimpulkan bahwa secara parsial Kepemimpinan $\left(\mathrm{X}_{1}\right)$ berpengaruh terhadap Kinerja Karyawan (Y) sebesar 71,6\% sedangkan sisanya 28,4\% dipengaruhi oleh faktor-faktor lain yang tidak diteliti dalam penelitian ini.

2) Terdapat pengaruh positif dan signifikan Budaya Organisasi $\left(\mathrm{X}_{2}\right)$ terhadap Kinerja Karyawan (Y). Hal ini ditunjukan oleh model regresi $\mathrm{y}=5,683+0,716 \mathrm{X}_{1}$ dan nilai $\mathrm{t}_{\text {hitung }}>$ $t_{\text {tabel }}(10,148>1,660)$, dengan nilai signifikansi sebesar $0,00<\alpha=0,05$, maka Hipotesis $\left(\mathbf{H}_{\mathbf{a}}\right.$ diterima $)$. Nilai Koefisien Determinasi $\mathrm{R}$ Square $\left(\mathrm{R}^{2}\right)$ sebesar 0,512, maka dapat disimpulkan bahwa secara parsial Budaya Organisasi $\left(\mathrm{X}_{2}\right)$ berpengaruh terhadap Kinerja Karyawan (Y) sebesar 51,2\% sedangkan sisanya 48,8\% dipengaruhi oleh faktor-faktor lain yang tidak diteliti dalam penelitian ini.

3) Tedapat pengaruh positif dan signifikan Motivasi Kerja $\left(\mathrm{X}_{3}\right)$ terhadap Kinerja Karyawan (Y). Hal ini ditunjukan oleh model regresi $\mathrm{y}=1,937+0,799 \mathrm{X}_{1}$ dan nilai $\mathrm{t}_{\text {hitung }}>$ $t_{\text {tabel }}(13,174>1,660)$, dengan nilai signifikansi sebesar $0,00<\alpha=0,05$, maka Hipotesis $\left(\mathbf{H}_{\mathbf{a}}\right.$ diterima). Nilai Koefisien Determinasi $\mathrm{R}$ Square $\left(R^{2}\right)$ sebesar 0,639, maka dapat disimpulkan bahwa secara parsial Motivasi Kerja $\left(\mathrm{X}_{3}\right)$ berpengaruh terhadap Kinerja Karyawan (Y) sebesar 63,9\% sedangkan sisanya 36,1\% dipengaruhi oleh faktor-faktor lain yang tidak diteliti dalam penelitian ini.

4) Terdapat pengaruh positif dan signifikan Kepemimpinan $\left(\mathrm{X}_{1}\right)$, Budaya Organisasi $\left(\mathrm{X}_{2}\right)$ dan Motivasi Kerja $\left(X_{3}\right)$ terhadap Kinerja Karyawan (Y). Hal ini ditunjukan oleh nilai $\mathrm{f}_{\text {hitung }} 87,670>2,70 \mathrm{ft}_{\text {tabel }}$, dengan nilai signifikansi sebesar $0,00<\alpha=0,05$, maka Hipotesis ( $\mathbf{H}_{\mathbf{a}}$ diterima). Nilai Koefisien Determinasi $\mathrm{R}$ Square $\left(\mathrm{R}^{2}\right)$ sebesar 0,733, maka dapat disimpulkan bahwa secara simultan Kepemimpinan ( $\left.\mathrm{X}_{1}\right)$, Budaya Organisasi $\left(X_{2}\right)$ dan Motivasi Kerja $\left(X_{3}\right)$ berpengaruh terhadap Kinerja Karyawan (Y) sebesar $73,3 \%$ sedangkan sisanya $26,7 \%$ 
dipengaruhi oleh faktor-faktor lain yang tidak diteliti dalam penelitian ini.

\section{B. SARAN}

Pembahasan dan kesimpulan di atas, maka peneliti dapat mengungkapkan beberapa saran sebagai berikut:

1. Pimpinan seharusnya memberikan kesempatan kepada karyawan untuk mendiskusikan masalah-masalahnya sehingga karyawan ketika ada masalah mendapatkan bantuan dari pimpinannya.

2. Budaya organisasi yang kuat seharusnya menimbulkan tuntutan yang berorientasi kepada hasil kerja yang tinggi dalam bekerja sehingga menghasilkan produktifitas yang optimal.

3. Motivasi kerja seharusnya dapat dibangun oleh pimpinan dalam berkomunikasi dengan bawahannya dengan tutur bahasa yang sopan sehingga membangkitkan motivasi kerja bagi karyawannya.

4. Kinerja karyawan seharusnya dituntut mengerjakan suatu pekerjaan dangan penuh perhitungan, cermat dan teliti sehingga kinerja yang didapat optimal.

\section{DAFTAR RUJUKAN}

Arikunto, Suharsimi (2014). "Prosedur Penelitian Suatu Pendekatan Praktek". Jakarta: Rineka Cipta.

Ariyanto, A., Nuryani, A., \& Sunarsi, D. (2020). Pengaruh Store Atmosphere Dan Promosi Terhadap Keputusan Pembelian Pada Alfamart BSD Tangerang Selatan. Jurnal Ekonomi Efektif, 3(1).

Basu Swastha Dharmmesta. (2014). Manajemen Pemasaran. BPFE: Yogyakarta. Buchari Alma. 2014. Manajemen pemasaran dan Pemasaran Jasa. Edisi Revisi.

Bilson Simamora (2016) Panduan Riset Prilaku Konsumen, Jakarta: PT. Gramedia Pustaka.

Dede Andi, Muhamad Abid, Denok Sunarsi, \& Irfan Rizka Akbar. (2021). Implementasi Pendidikan Karakter Melalui Nilai-nilai Kearifan Lokal di Mts Darul Huda Kp. Cimuncang Kabupaten - Tasikmalaya. JIIP Jurnal Ilmiah Ilmu Pendidikan, 4(3), 149153. Retrieved from http://jiip.stkipyapisdompu.ac.id/jiip/inde x.php/IIIP/article/view/227
Fadli, R. (2019). Pengaruh Kepemimpinan Terhadap Kinerja Karyawan PT. Tunas Perkasa Tekindo. Jurnal Semarak: Jurnal Ilmiah Prodi Manajemen Universitas Pamulang, 2 (2), 85-100.

Fadli, R. (2020). Pelatihan Manajemen Waktu dalam Mewujudkan Produktivitas Kerja pada Tenaga Kesehatan RSU Bhakti Asih, Jurnal Baktimas, 2 (2), 100-103.

Fandy Tjiptono (2017), Serivce Quality and Satisfiation. Jakarta: Edisi tiga. Andi.

Freddy Rangkuti (2016) Strategi Promosi Yang Kreatif, Edisi Pertama, Cetakan Pertama Jakarta: Gramedia Pustaka Utama.

Haque, MG., Munawaroh, Sunarsi, D., (2020). Analysis of SMEs Culinary Marketing Strategy During Covid 19 Pancemic: A Study at "Sate Bebek Cilegon" Resto in Cilegon, Banten. International Journal of Education, Information Technology, and Others. Vol.3. Issue 2

Imam Ghozali (2017). "Aplikasi Analisis Multivariate Dengan Program SPSS". Edisi Kelima. Semarang: Badan Penerbit Undip.

Irmal, I., Gustiarani, E., \& Sunarsi, D. (2020). Pengaruh E-Marketing dan E-CRM terhadap E-Loyalty Pengunjung Situs Website www. Cangkirbogor. com. Jurnal Ekonomi Efektif, 2(2).

Istijanto (2014) "Riset Sumber Daya Manusia". Jakarta: PT. Gramedia Pustaka

Jasmani, J. (2018). Pengaruh Kualitas Produk Dan Harga Terhadap Keputusan Pembelian Pada PT. Baja Mandiri Di Jakarta. Disrupsi Binis, 1(1).

(2019). The Effect of Leadership and Competence on Lecturer Performance and Its Implications on Student Learning Motivation at Pamulang University. International Journal of Advances in Social and Economics, 1(4).

(2020). Analysis of the Effect of Prices, Promotions and Products on Purchase Interest Impacts on Consumer Satisfaction of VIVO Brand Mobile Phones in South Tangerang Region. Jurnal Ad'ministrare, 7(1), 73-82. 
Kasmad, K., Mustakim, M., \& Sunarsi, D. (2020). Increasing Community School Interest Through Service Quality, Prices and Promotion in Vocational High Schools. Journal of Educational Science and Technology (EST), 6(2).

Kharis, Ismu Fadli (2011). "Studi Mengenai Impulse Buying dalam Penjualan Online". Semarang : Skripsi Universitas Diponegoro

Kotler dan Amstrong (2017), Prinsip-prinsip Pemasaran. Edisi Kedua Belas". Jilid Satu. Jakarta: Erlangga.

Linda Suprihatin, \& Denok Sunarsi. (2021). Pengaruh Kepemimpinan Transaksional dan Lingkungan Kerja Terhadap Kinerja Pegawai di Pusat Pendidikan dan Pelatihan Pegawai Kementerian Pendidikan dan Kebudayaan. JIIP - Jurnal Ilmiah Ilmu Pendidikan, 4(1), 78-86. Retrieved from http://jiip.stkipyapisdompu.ac.id/jiip/inde x.php/IIIP/article/view/207

Lupiyoadi (2016) Manajemen Pemasaran Jasa, Edisi 4, Jakarta: Salemba Empat.

Maddinsyah, A., Hidayat, D., Juhaeri, J., Susanto, D., \& Sunarsi, D. (2020). Desain Formulasi Dan Implementasi Bisnis Strategik Dengan Pendekatan Business Model Canvas (BMC) Terintegrasi Kerangka Integrated Performance Management System (IPMS) Pada Koperasi Asperindo. Inovasi, 7(2), 6776.

Mani, J. (2017). Pengaruh Persepsi Merek Dan Kualitas Pelayanan Terhadap Kepuasan
Konsumen (Studi Kasus Pada PT. Bisma Narendra Di Jakarta). Jurnal Mandiri, 1(2), 187-206.

Philip Kotler (2017) Manajemen Pemasaran, Edisi Keempat Belas, Jakarta: PT. Indeks.

Phipil Kotler dan Kevin Keller (2017) Manajemen Pemasaran, Edisi Kedua Belas, Jilid Satu, Jakarta: Erlangga.

Rao, Purba, (2012). "Measuring Consumer Perceptions Through Factor Analysis", The Asian.

Santoso, Singgih (2015). "Menguasai Statistik Multivariat". Jakarta: PT Elex Media Komputindo.

Sudjana (2014) "Metode Statistika", Bandung: Tarsido.

Sugiyono (2017), "Metode Penelitian Administrasi : dilengkapi dengan Metode R \& D”. Bandung: Alfabeta.

Suhartanto (2014). "Metode Riset Pemasaran". Bandung: Alfabeta

Sunarsi, D. (2020). Pengaruh Bauran Pemasaran Dan Kualitas Pelayanan Terhadap Kepuasan Konsumen Pada Giant Dept Store Cabang BSD Tangerang. E-Mabis: Jurnal Ekonomi Manajemen dan Bisnis, 21(1).

Y Kadarusman, D Sunarsi. (2020). Pengaruh Strategi Penetapan Harga Terhadap Peningkatan Jumlah Siswa Pada SMK PGRI Balaraja. JS (JURNAL SEKOLAH) 4 (3), 213221. 